\title{
PANCA WASTA TEACHINGS AS A SOURCE OF INSPIRATION CREATION FOR DHAPUR KRIS
}

\author{
Haris Fajar Nugroho ${ }^{1}$ and Dharsono ${ }^{2}$ \\ ${ }^{1}$ Institut Seni Indonesia (ISI) Surakarta, Indonesia \\ 2 Institut Seni Indonesia (ISI) Surakarta,Indonesia \\ E-mail correspondence: hariskrisisiska@gmail.com
}

\begin{abstract}
Panca Wasta is a teaching at the level of family life which contains advice on values that elevate human position in personality, nobility, welfare and knowledge that must be possessed by a man (Javanese) in particular. The focus of the creation of the work is in the form of a kris blade which is inspired by the five elements of the Panca Wasta teachings which contain; wisma, turangga, kukila, curiga and wanita, using recycled metal. The purpose of the creation of this work is to create a dhapur kris blade using recycled metal with a metaphorical tinatah motif from the five elements of the panca wasta teachings. The creation of works uses an artistic creation approach, namely; experiment, contemplation and embodiment of works. The resulting work is a kris blade complete with warangka, hulu/jejeran/ukiran, mendhak, and pendok of Surakarta style. When the teachings of Panca Wasta are used as the concept of creating a kris, it shows that the work of a kris is quite interesting, has aesthetic beauty and full of philosophical values and meanings.
\end{abstract}

Keywords: Panca Wasta, kris, and waste recycling.

\begin{abstract}
ABSTRAK
Panca Wasta merupakan ajaran tataran urip bebrayan yang berisi petuah tentang nilai-nilai yang mengangkat kedudukan manusia pada kepribadian, keluhuran, kesejahteraan dan ilmu pengetahuan yang harus dimiliki oleh seorang pria (Jawa) khususnya. Fokus penciptaan karya berupa bilah kris yang terinspirasi dari lima unsur ajaran Panca Wasta yang berisi; wisma, turangga, kukila, curiga dan wanita, dengan menggunakan logam daur ulang. Tujuan dari penciptaan karya ini yaitu menciptakan bilah kris dhapur kreasi menggunakan logam daur ulang dengan motif tinatah metafora dari kelima unsur pada ajaran panca wasta. Penciptaan karya menggunakan pendekatan kreasi artistik yaitu; eksperimen, perenungan dan perwujudan karya. Karya yang dihasilkan adalah sebuah bilah kris lengkap dengan warangka, hulu/jejeran/ukiran, mendhak, dan pendok gaya Surakarta. Ketika ajaran Panca Wasta dijadikan konsep penciptaan karya kris, menunjukkan hasil karya kris yang cukup menarik, memiliki keindahan estetis dan sarat dengan nilai dan makna filosofis.
\end{abstract}

Kata kunci: Panca Wasta, kris, dan daur ulang limbah. 


\section{Artistic}

\section{Introduction}

UNESCO has inaugurated The Indonesia Kris a Masterpiece of the Oral and Intangible Heritage of Humanity on November 25, 2005. Based on this recognition, UNESCO has recognized that the kris is a cultural heritage of material (intangible) and non-tangible. Kris is one of the many original world cultural heritages of the Indonesian people, which need to be preserved and conserved both in terms of preservation and conservation. The kris is a work of the original cultural heritage of the Indonesian people which is estimated to have existed since before the 10th century, referring to several artifacts found on the temple reliefs that have forms resembling a kris which are then interpreted as a form of the appearance of a kris (Hasrinuksmo, 2004).

Kris as an artifact (ideofact) becomes a cultural heirloom for the beliefs of the community in the presence of myths, hist(Hasrinuksmo, 2004)orical stories and folklore. The kris, which was used in the past as a stabbing weapon in war (technofact), was later used as a status for body equipment or accessories (ageman) or official palace clothing, and was also worn on traditional Javanese ceremonial clothing (sosiofak) (Yuwono, 2012). Kris are created with various philosophical backgrounds, and sometimes use teachings in Javanese culture as the basis for their creation.

The panca wasta teachings were used as a source of inspiration for the creation of this dhapur kris creation. The panca wasta teachings are; wisma ${ }^{1}$, turangga ${ }^{2}$, kukila $^{3}$, curiga $a^{4}$ dan wanita ${ }^{5}$. Meanwhile, the perspective of the creation of the kris is focused on the typology of the blade and the motif tinatah of kris. The resulting work is a kris blade, and the presentation of the work is equipped with

\footnotetext{
${ }^{1}$ Wisma in the Javanese-Indonesian dictionary means house.

2 Turangga in the Javanese-Indonesian dictionary means vehicle, in feudal times it was synonymous with horses.

${ }^{3}$ Kukila in the Javanese-Indonesian dictionary means bird.

${ }^{4}$ Curiga or dhuwung in Javanese terms can be interpreted as a kris, as in the terms " Curiga manjing warangka, warangka manjing curiga, jumbuh manunggaling kawula lan Gusti"

${ }^{5}$ Wanita in the Javanese dictionary means woman.
} 
warangka, hulu/jejeran/ukiran, mendhak, and pendok of Surakarta style.

Panca Wasta is a teaching about tataran urip bebrayan ${ }^{6}$ which contains advice on values that elevate human position as a guide or foundation of life related to personality, nobility, welfare and knowledge that must be possessed in order to achieve a perfect or ideal life. In "Serat Wedatama" by KGPAA Sri Mangkunegara IV, the 29th stanza, contains three things that can elevate human position, namely; rank, wealth and intelligence (wirya harta tri winasis). If humans do not have one of the three, then there is no meaning as a human being, likened to more valuable dried teak leaves, so that their lives will become beggars or vagrants (Jatmiko, 2020). In the world of Tosan Aji there is also the term Warangka manjing curiga, Curiga manjing Warangka, Jumbuh Manunggaling Kawula lan Gusti"which symbolically implies the relationship of unity between humans and their God and humans with each other.

The teaching of Panca Wasta become a source of inspiration, especially aspects of value and philosophical meaning, as a provision for reflection/ contemplation in the metaphorical process in the creation of this work. In addition, it is also to stimulate and strengthen emotions in visualizing the typology and motifs of tinatah that will be produced. This is expected to create beauty in the work of the resulting bilah kris blade. The creation of this work in the form of a dhapur kris, emphasizes creativity in the embodiment of the work. It is based on works of past cultural heritage as a reference and is accompanied by working innovations (Dharsono, 2012).

The teaching of Panca Wasta has philosophical meanings, spiritual values, social values, personal values and moral messages. This teaching is the basis of life in an effort to control attitudes, behavior, noble personality, welfare and knowledge that one must possess. The foundation of human life to be able to achieve a perfect (ideal) household life is interesting as a source of inspiration for the creation of this kris.

${ }^{6}$ Tataran means level, grade, degree, strata or quality. Urip means Life. Bebrayan in Javanese means interacting or socializing. 


\section{Artistic}

Teachings that have existed hundreds of years ago, seem to be quite relevant if applied today, because human needs are increasing by recognizing style and prestige, and their existence is not only interpreted literally. Thus, these teachings deserve to be appointed as the creation of works of art. So that, the problem can be formulated, namely how to create a kris blade based on the teaching of Panca Wasta?

\section{Literature Review}

Javanese society have many ways in life to be able to achieve perfection or the achievement of an ideal life. Attitudes and behavior in life are matters of many dreams that can be implemented through a teaching. Living with teaching as a provision of attitude, in general, Javanese people have guidelines or foundations for realizing life goals (Endraswara, 2016). The Javanese way of life has been rooted into daily norms to realize self-peace, harmony and perfection of life (Murtisari, 2013).

The Panca Wasta teaching is one of the many concepts of the perfection of life, containing the wisma, turangga, kukila, wanita and curiga. For a man (Javanese) in particular, the term is not just a slogan or expression (unen-unen), its existence becomes a teaching to build self-motivation as a perfect human being in accordance with the context of Javanese culture (Basuki, Suyanto, and Hartoyo, 2020). The emergence of expressions containing this teaching is not known for certain since when it appeared. A provisional assumption is that the Panca Wasta teaching is a form of oral culture that the existence is taught from generation to generation (getok tular) (Endraswara, 2016). Teachings can influence human thinking, imagination and psychology so that they become the basis or foothold in behaving in everyday life (Sartre, 2016).

Men (Javanese) can be called "njawani" if they have been able to obey Javanese traditions and procedures. Being able to become a cultured human being or a civilized human being and understanding about the tataran urip bebrayan (Mulder, 1983). A person's Javaneseness (njawani) can grow naturally, not only can be seen 
from the age factor. Various things related to speech, attitudes, expressions, actions towards others, actions to the nature environment and others can present their personality in aspects of spiritual, social and personal values (Endraswara, 2003).

Five conditions of perfection as a man (Javanese) are symbolically in the teachings of Panca Wasta, among others:

1) Wisma, literally means house. Wisma is a form of guarantee of establishment, in this case it is different from the omah. Wisma is a place to live that is able to provide comfort, stability, glory and honor. As a human being whose identity is clear, his social strata is clear, his existence is clear (Yuwono, 2020). A man must be able to angomahi (making the house as a shelter) (Endraswara, 2003).

2) Wanita, literally means woman. Women are symbolically a guarantee of descent or angamatjani (able to produce superior children), because Javanese society at that time adhered to the "puruse" system or male lineage (Yuwono, 2020). The concept of men in choosing women by considering bibit (descendants), bobot (wealth) and bebet (position) (Endraswara, 2003).

3) Turangga, literally means vehicle. In the kingdom of the past, was more synonymous with horses. A Javanese man must have a vehicle or intermediary in order to be able to convey knowledge, broad insight, able to understand life with experiences. In Javanese terms, it is called "ngerti genon" or being able to understand other places, far away places (Yuwono, 2020). As a figure who is able to angayomi (become a protector and guide for the family) in maintaining family conditions that are safe, peaceful and free from disturbances (Endraswara, 2003).

4) Kukila, literally means bird. The depiction of birds symbolically has a meaning in the aspect of beauty, being able to chat, communicate, build a harmony with each other well. The meaning contained is that a man in particular, must have intelligence as a provision for social life related to socializing in society by selectively choosing good words and behavior. Words or expressions that come out verbally must always emit spiritual content (charismatic) for themselves and 


\section{Artistic}

others who listen to them, so that the words issued can be transformed into a form of obedience (Basuki, Suyanto, Hartoyo, 2020).

5) Curiga, symbolically and identically with the kris. The existence of the kris as a symbol of strength that being a man must be lanthip (brilliant), intelligent, responsive, gentle, and able to protect. In this context, curiga is not referred to as dhuwung, in the world of tosan aji and Javanese philosophy there are the terms curiga manjing warangka, warangka manjing curiga, jumbuh manunggaling kawula lan gusti. The unity of the people with God occurs in an intuitive process called Kasunyatan Jati, meaning that a perfect human being, both in character and hastasila, becomes the same or manunggal (united) with God's lofty nature. Humans are no longer controlled by dreams, feelings and passions, instead they tend to perform the highest function, namely being aware, believing, and obeying God, and finding true truth and wisdom by mastering their outer nature and descending into their own depths (Purwowiyoto, 2016).

The five elements contained in the Panca Wasta teachings become a single unit that will reflect the values contained in it, including:

a) Spiritual Value, that as a human being must understand the greatness of God Almighty, understand religious teachings so that they are able to worship (pray) properly for the form of perfection that has been achieved in their lives.

b) Social Values, which reflect a great sense of responsibility to family, guests, and others. Therefore, for the Javanese people, it is forbidden to have a small house door, having an uninsulated porch (emper) that reflects openness to anyone who comes and stops in it.

c) Personal Values, which are able to trigger and motivate him to achieve the perfection of life in the context of Javanese culture.

The wider context of the Panca Wasta teaching is as a reflection of the effort to "memayu hayuning Bawana". The elements contained in these teachings are able

to bring human to the harmony of life. The teachings of Panca Wasta are very important for Javanese people in living life, if it is based on the "Serat Wedatama" 
by KGPAA Sri Mangkunegara IV, the 29th stanza which contains the following.

"Bonggan kan tan merlokeno,

Mungguh ugering ngaurip,

Uripe lan tripakara,

Wirya, arta tri winasis,

Kalamun kongsi sepi,

Saka wilangan tetelu,

Telas tilasing janma,

Aji godhong jati aking,

Temah papa papariman ngulandara”

("It's his own fault for not caring,

On the basis of livelihood,

Life is based on three things,

Nobility, welfare and knowledge,

If you don't have,

One thing out of the three,

End of meaning as a human,

Still more valuable dry teak leaves,

Finally suffers from being a beggar and a homeless person”) (Suyanto, 2019)

The main values of Javanese personality become guidelines and motivations to

live life according to existing values, strive to manage feelings (bathin), and determine actions and attitudes that are in accordance with Javanese cultural values (lakutama or main behavior) (Trimulyaningsih, 2017).

\section{Creation Methodology}

According to Haryono Haryoguritno, three components are the basis for creating works of art, namely:

1) Greget is an impression that can evoke emotions from people who observe works of art, including kris. In Bali it is called taksu. Greget can upload or lower someone's passion.

2) Guwaya kris blade is an impression that implies the vitality and spirit of the kris blade. For example, people who are in good health will appear guwaya (brighter facial expressions, more radiant eyes, full of enthusiasm for life). Guwaya is a psychological and spiritual effect. 


\section{Artistic}

3) Wangun means 'anatomical compatibility'. In fact, there are many kris that look wagu (odd/strange/peculiar). This should actually be avoided even though the kris contains positive values in other aspects, such as iron, steel, process, age, condition, or peculiarities. The definition of wagu is not the same as the difference in the shape of a dhapur based on the maker, the time it was made, and the place of origin. So, does not represent any particular style (tangguh). The peculiarities of the form leads to the understanding of aesthetic errors due to the lack of knowledge and experience of the maker, restoration errors, or due to pasikutan (Haryoguritno, 2006).

Fundamentally and in accordance with the creative process described in the Kreasi Artistik book (Dharsono, 2016), the stages in the creation of this kris include:

a) Experiment (research of material), is a stage carried out in the artistic creation process which includes; (1) trying to explore the materials of the kris blade using steel wire armor from the remnants of human activities in electrical and instrument installations in one of the infrastructure developments in the Krakatau Steel area, Cilegon, Banten, Indonesia; (2) trying several alternative individual techniques to apply pamor rekaan (pamor creation) designs to the resulting kris blades; and (3) trying to make several alternative sketches and working drawing designs to apply typological forms and tinatah motifs to the resulting kris work.

b) Contemplation (research of feelings), also called inner wandering, which is a stage of contemplation to be able to find and pour inspiration on the typology of the blade, and the main motif as the tinatah motif on the kris blade. Contemplation can be done by means of meditation and so on. The results of the acquisition of reflection can be in the form of shapes, symbols, icons, and motifs that can be used in designing sketches and designs.

c) Formation, which is a process of forming blades and tinatah motifs according to the chosen alternative sketch and has been refined into a sketch. Furthermore, working drawings are used as a reference in the process of forming the work. 
The creation of the dhapur kris blade creation was inspired by the teachings of Panca Wasta with a variety of blade typologies, tinatah motifs and pamor motifs produced. The presentation of the work is equipped with warangka, hulu/jejeran/ukiran, pendok, and mendhak.

Technically, the creation of this kris is done with the following steps.

1). Creation of kris blade

The creation of the work is based on the dhapur kris standard (pakem), among others; condong leleh and rericikan as babon (reference). The creation of this work uses the concept of reinterpretation of sanggit by utilizing ideas and idioms.

2). Creation of tinatah motif

The creation of the tinatah motif is made using the concept of metaphor and is based on the five elements that exist in the teachings of Panca Wasta. Metaphor is a working process by utilizing the source of traditional ideas and idioms with a structure that refers to the technique of visualizing works personally (Dharsono, 2016).

\section{Discussion}

\subsection{Creative Process}

\subsubsection{Kris Blade Sketch}

Before arriving at the process of creating the work, it is necessary to have an initial plan with contemplation to make several sketches of the kris blade which is then selected and can be used as a guide in the process of realizing the work.

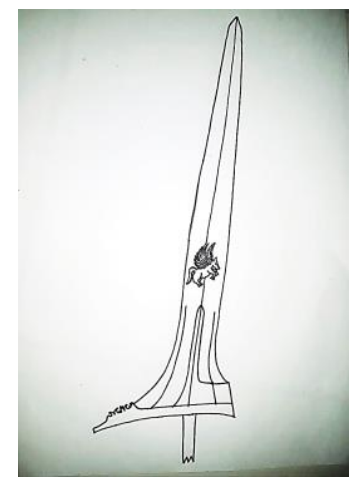

Figure 1. Sketch of kris blade (left side view)

(Photo: Nugroho, 2020) 


\section{Artistic}

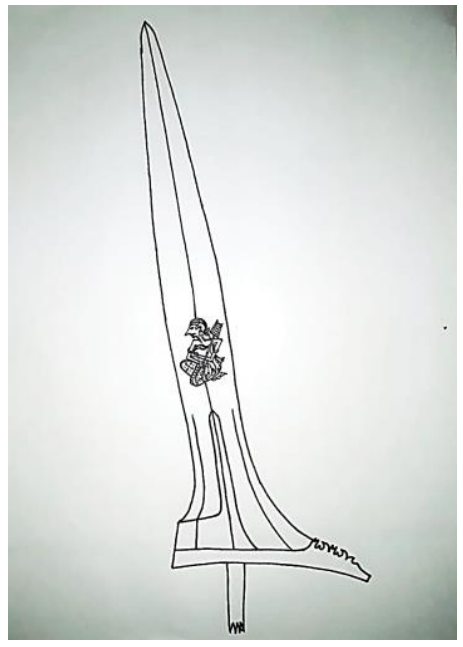

Figure 2. Sketch of kris blade (right side view).

(Photo: Nugroho, 2020)

\subsubsection{Working Step}

\section{1). Experiment (media/medium research)}

The use of alternative materials, namely; iron $(\mathrm{Fe})$, steel wire armor (SWA) and steel (C). SWA is a shield (armour) that serves to protect the insulation layer to prevent mechanical damage in a cable. Its main role is as an anti-burn protection in the event of an electrical short circuit or fire. Based on the shape, it is classified into three types, namely: steel tape armor, steel wire armor, and aluminum armor.

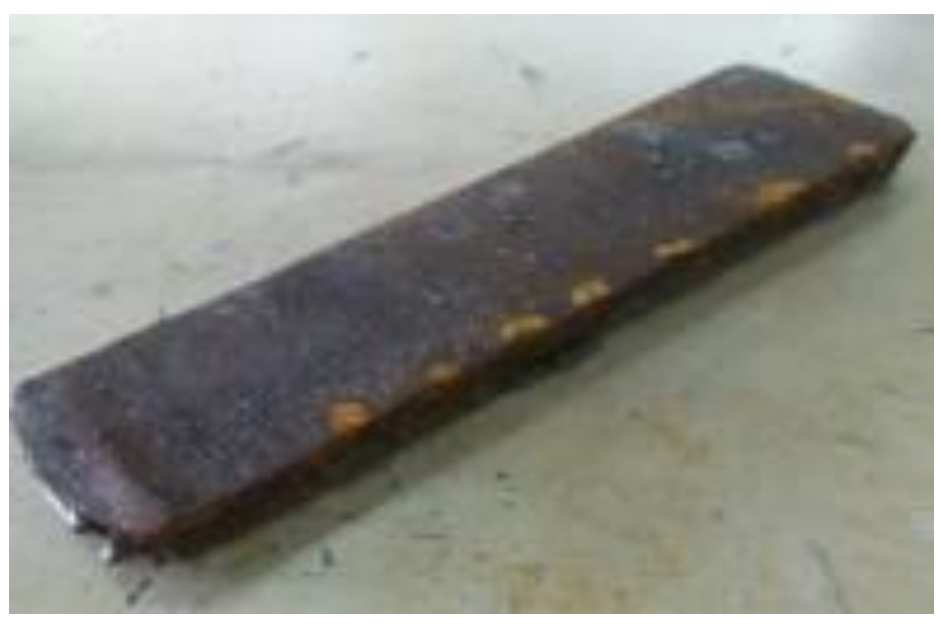

Figure 3. Flat iron (Fe) $10 \mathrm{~mm}$ thick.

(Photo: Nugroho, 2019) 


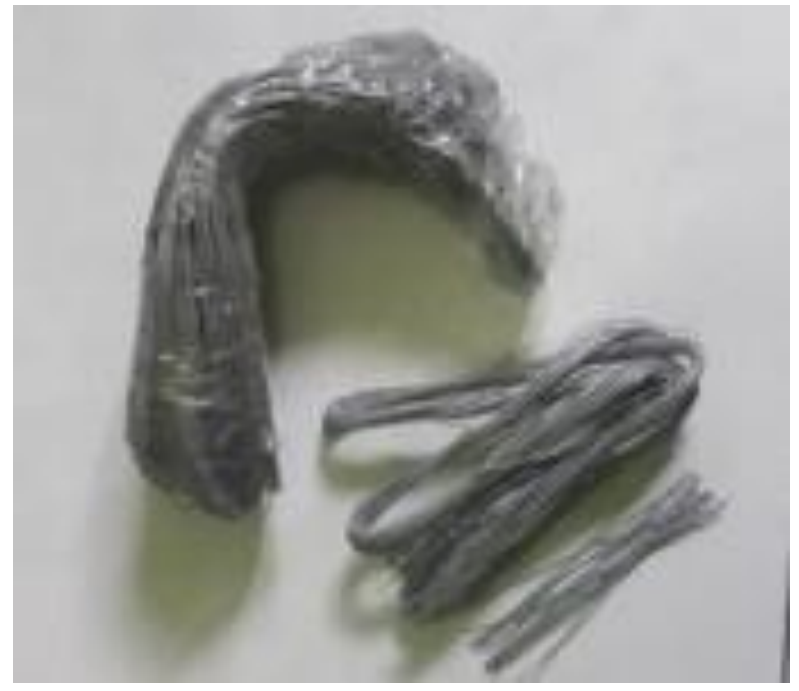

Figure 4. Stell Wire Armour (SWA). (Photo: Nugroho, 2019)

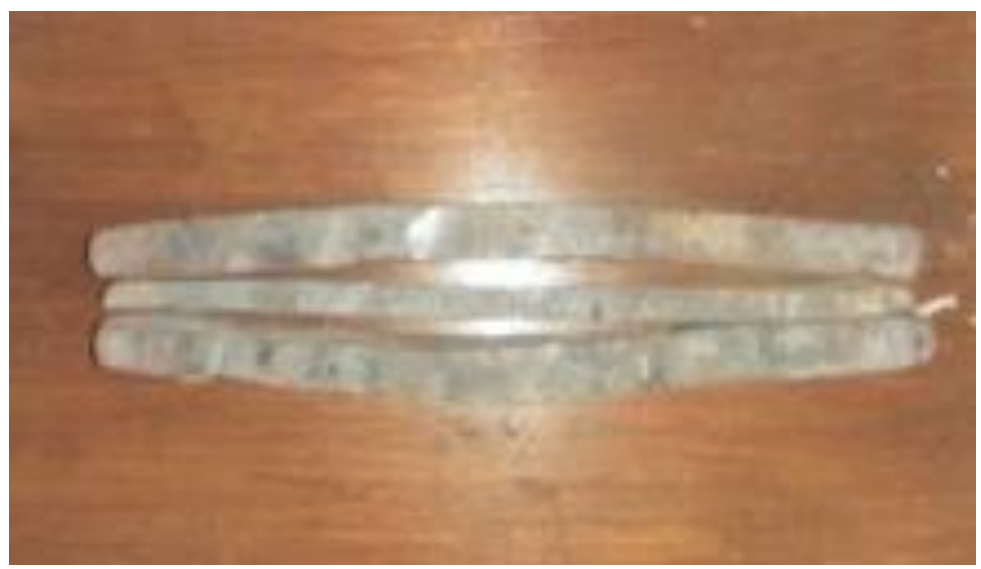

Figure 5. Baja/ steel (C) strip peer (Photo: Nugroho, 2019)

Steel Wire Armor (SWA) with a diameter of $2 \mathrm{~mm}$ and a weight of 2 ounces and iron $(\mathrm{Fe})$ with a thickness of $10 \mathrm{~mm}$ and a weight of $1.5 \mathrm{~kg}$ are combined through a forging process. By using the folding technique as many as 128 folds can produce an alloy of iron. The resulting alloy is used as a pamor material on the surface of the kris blade. Steel (C) weighing $0.5 \mathrm{~kg}$ with a thickness of $0.5 \mathrm{~mm}$ is used as a slorok, to sharpen both sides of the kris blade. The use of gold weighing 3 grams on the tinatah motif aims to add the aesthetic beauty and make the tinatah motif appear more prominent. 


\section{Artistic}

This material experiment is expected to be used as knowledge about alternative new formulas in processing the pamor of kris blades. It is also a medium of expression as well as a reflection of environmental care, by utilizing waste/used goods to produce an aesthetic and high-value art object.

2). Kris Blade Forging

The forging of the kris can be explained as shown in the picture below.

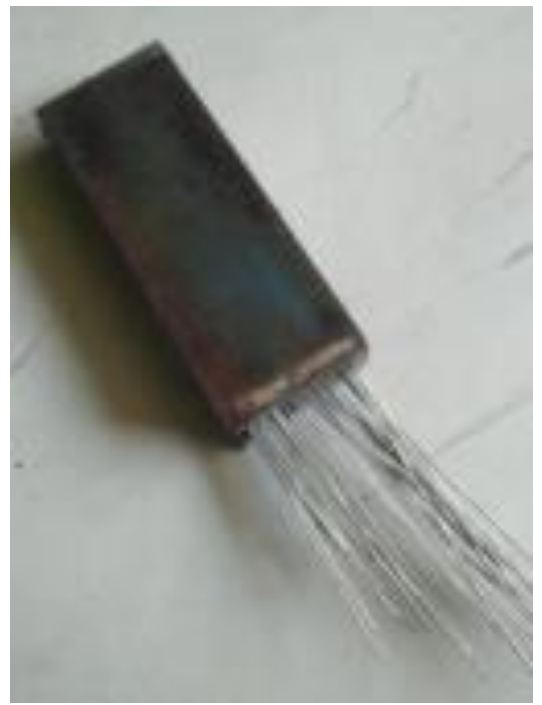

Figure 6. The process of the early stages of iron folding and SWA.

(Photo: Nugroho, 2019)

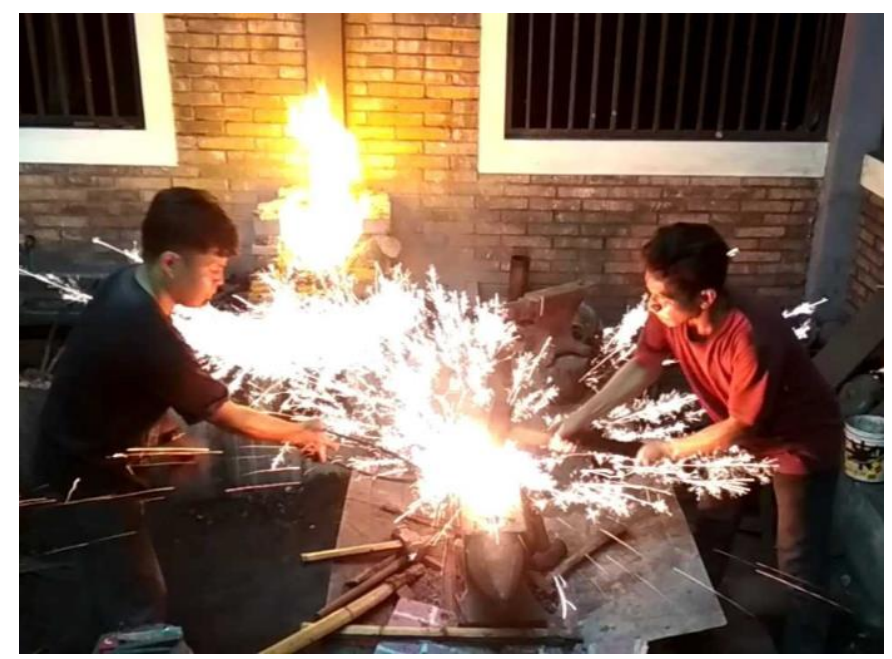

Figure 7. Incandescent process (uniting several metal elements into one).

(Photo: Harmawan, 2019) 


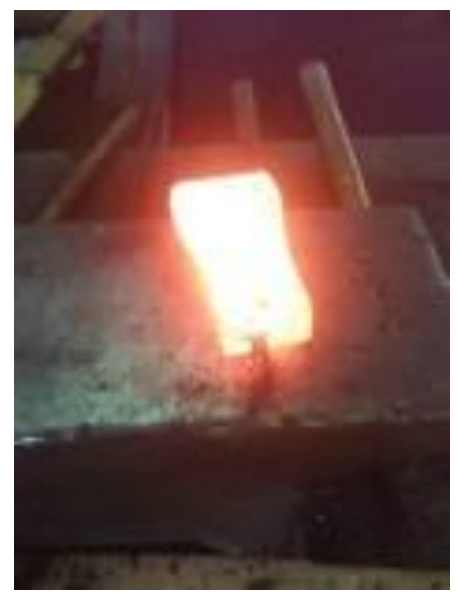

Figure 8. Iron and SWA after going through the incandescent process. (Photo: Nugroho, 2019)

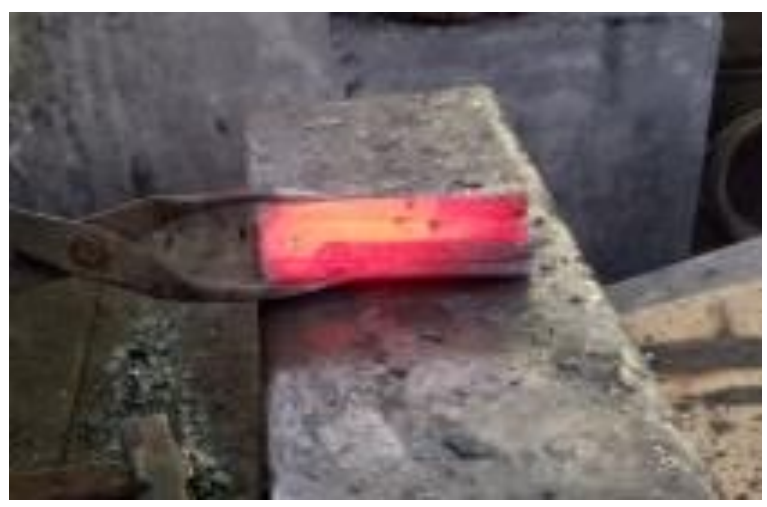

Figure 9. The "ngulet" process, folds 1, 4, 16, 32, 64 and 128. (Photo: Nugroho, 2019)

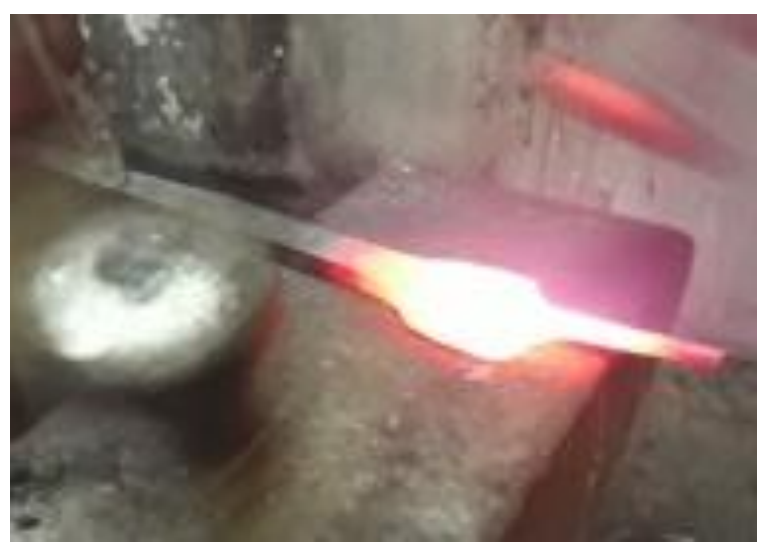

Figure 10. The process of formation of kodokan of kris and blades stem (Photo: Nugroho, 2019) 


\section{Artistic}

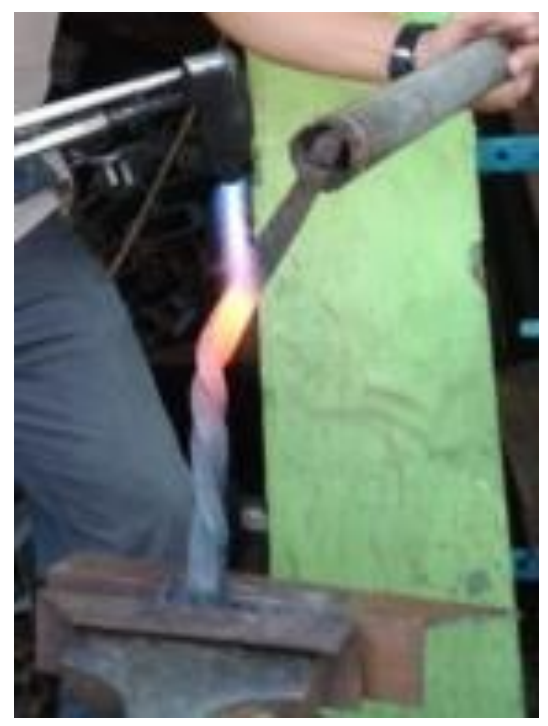

Figure 11. The process of "puntir" technique (Photo: Arissadewa, 2019)

3). Kris Blade Formation

The making of the kris blade is carried out through several stages, namely kodokan/bakalan, tinatah, nyangling, and warangan, with the following explanation. a). Making kodokan (bakalan blades)

After the Kodokan blades have been made, the next process is finishing using a grinder machine, kikir, pahat besi (iron chisel) and mini grinder. The use of a grinder machine to form blades according to the sketch that has been made.

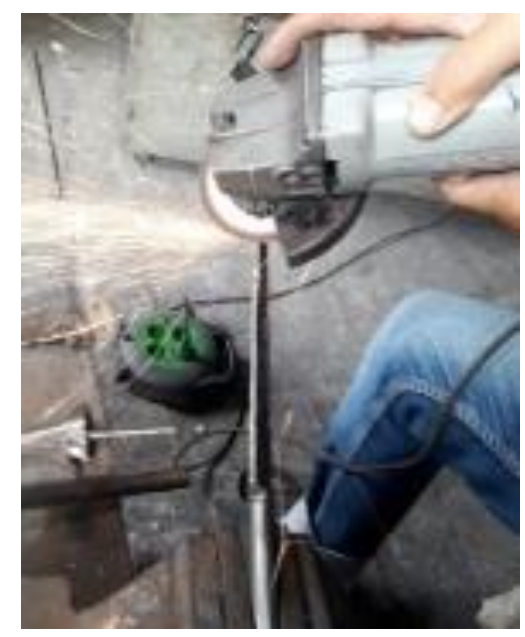

Figure 12. The process of forming blades with a grinder machine.

(Photo: Arissadewa, 2019) 
b). Tinatah on the blade

Tinatah comes from the words "ti" (di) and "tatah" (chisel), which can be interpreted as the process of giving certain motifs to the surface of the kris blade using a chisel tool.

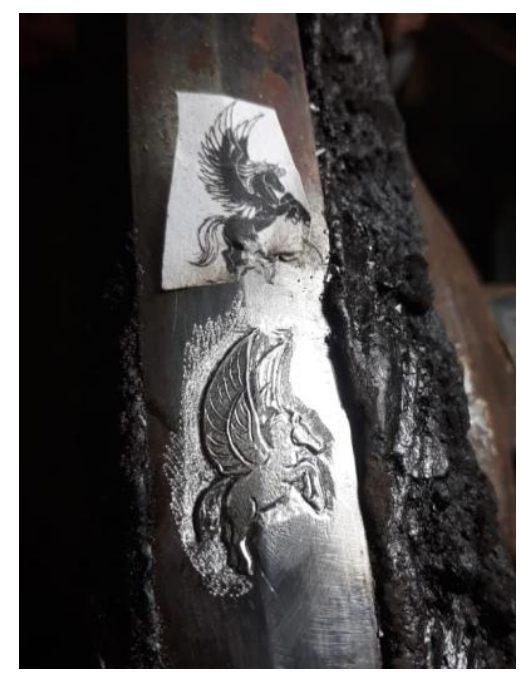

Figure 13. The process of making a tinatah motif on the blade.

(Photo: Nugroho, 2019)

c). Nyangling

Nyangling is the process of refining the kris blade. This is done before the warangan/jamasan stage. The smoothing carried out aims to remove scratches from the grinder machine and kikir as well as carvings on the blade. The way to smooth it is by rubbing it with a sharpening stone (wungkal) with various textures from the coarsest to the smoothest.

d). Warangan

Pewarangan is the process of dipping a clean blade into warangan liquid. Warangan liquid is made from arsenic trisulfide (As2S3) mixed with lime juice. There are several benefits and objectives of pewarangan including:

a) Removes rust on the entire surface of the blade.

b) Prevents and slows down corrosion of the blade because after being treated the surface of the blade is covered by a layer of arsenic.

c) Pewarangan makes the pamor motif clearer, so that the blade looks more 


\section{Artistic}

beautiful.

d) Can bring out the difference in the color of iron and steel wire armor or nickel (Haryoguritno, 2005).

\subsection{Artwork}

After the kris blade is finished, other parts also need to be worked on, namely the warangka and pendok. When everything is complete, a kris is produced as shown below.

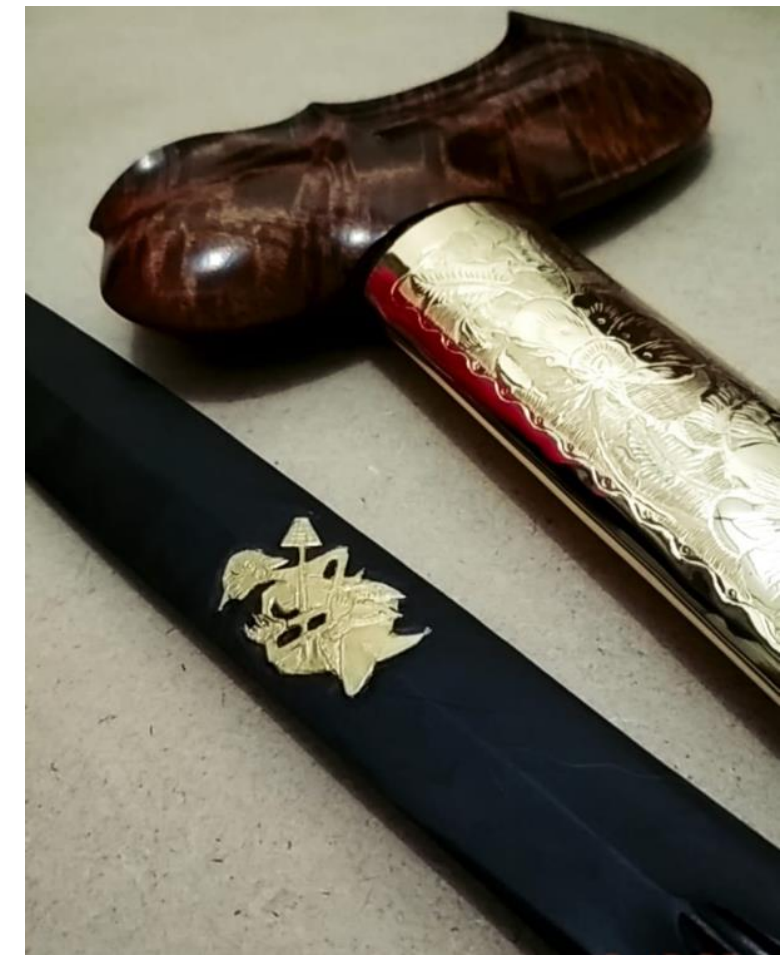

Figure 14. "Kris Panca Wasta”, steel wire armour, iron, nickel and steel, 128 folds from forging process (Photo: Nugroho, 2019).

The specification of the work is Kris Panca Wasta, Steel Wire Armor (SWA) blade material, iron (Fe), steel (C) and gold, pamor Puntir, Acacia wood (Acacia Mangium) warangka material, Surakarta Gayaman warangka, gold plated copper pendok. pendok Bunton Surakarta, mendak Mrican, hulu/deder Acacia wood (Acacia Mangium), and hulu species Nunggak Semi Surakarta. 


\section{Conclusion}

Javanese men based on the existence of Panca Wasta teachings which contain: wisma, turangga, kukila, curiga and women, place men in more duties and responsibilities when compared to women. The existence of Panca Wasta teachings that existence is still very relevant if applied in the modern era, namely as the foundation of life that is able to bring humans to achieve perfection in life according to the criteria and context of Javanese culture. Being an Njawani is not only seen from natural factors (age and maturity), but also how a person who has been able to adhere to his principles, traditions and culture.

When the teachings of Panca Wasta are used as a concept for the creation of a kris, it shows the results of an artwork that are quite interesting. The work of the Panca Wasta kris was produced through experimentation with alternative materials by utilizing the waste left over from human activities with artistic creation methods and forging techniques. From the artistic creation process, kris is produced which has aesthetic beauty and is full of philosophical values and meanings. The creation of this kris is one of the efforts to be able to "memayu hayuningbawana", "memayu hayuning sasama" and "memayu hayuning bebrayan".

\section{References}

Dharsono. (2012). Sejarah Tosan Aji (Kris). Semarang: Dinas Kebudayaan dan Pariwisata Provinsi Jawa Tengah.

Dharsono. (2016). Kreasi Artistik, Perjumpaan Tradisi Modern dalam Paradigma Kekaryaan Seni. Karanganyar: LPKBM Citra Sain.

Endraswara, S. (2003). Falsafah Hidup Jawa. Yogyakarta: Cakrawala.

Endraswara, S. (2016). Metodologi Penelitian Ekologi Sastra: Konsep, Langkah dan Penerapan. Yogyakarta: Caps.

Haryoguritno, H. (2005). Kris Jawa, Antara Mistik dan Nalar. Jakarta: PT. Indonesia Kebangsaanku.

Haryoguritno, H. (2006). Keris Jawa: Antara Mistik dan Nalar. Jakarta: PT. Indonesia Kebanggaanku.

Hasrinuksmo, B. (2004). Ensiklopedi Kris. Jakarta: Pratama Gramedia.

Jatmiko, A. (2020). Buku Tafsir Ajaran Serat Wedhatama. Yogyakarta: Pura Pustaka. 


\section{Artistic}

Mulder, N. (1983). Kebatinan dan Hidup Sehari-Hari Orang Jawa. Yogyakarta: Gadjah Mada University Press.

Murtisari, E. T. (2013). Some Tradisional Javanese Values in NSM: from God to Social Interaction. International Journal of Indonesian Studies.

Purwowiyoto, B. S. (2016). Magnum Opus (Karya Besar): Chandra Jiwa Indonesia (Warisan Ilmiah Putra Indonesia). H\&B/ Heart \& Beyond PERKI.

Sartre, J.-P. (2016). Dinding. Yogyakarta: Octopus.

Trimulyaningsih, N. (2017). Konsep Kepribadian Matang dalam Budaya Jawa-Islam: Menjawab Tantangan Globalisasi. Buletin Psikologi.

Yuwono, B. T. (2012). Keris Indonesia. Karanganyar: PT Keris Nusantara Lestari \& Citra Sains LPKBN.

Yuwono, B. T. (2020, February 5). Interview about Kris.

\section{ARTISTIC : International Journal of Creation and Innovation}

Publisher:

Program Pascasarjana

Institut Seni Indonesia (ISI) Surakarta

Available online at:

https://jurnal.isi-ska.ac.id/index.php/artistic

How to Cite:

Nugroho, Haris Fajar \& Dharsono. (2021). Panca Wasta Teachings as A Source of Inspiration Creation for Dhapur Kris. ARTISTIC : International Journal of Creation and Innovation, 2(1), 52-68 